\title{
Fine structural evidence for hormone secretion by the human thymus
}

\author{
J. M. VETTERS AND R. F. MACADAM \\ From the University of Glasgow, Department of Pathology, Western Infirmary, Glasgow
}

SYNOPSIS The epithelial cells of the Hassall's corpuscles in 11 human thymus glands (nine cases of myasthenia gravis and two glands from patients undergoing surgical correction of congenital heart disease) have been examined by electron microscopy. In every instance the epithelial cells have the cytoplasmic organelle complex necessary for 'export'-type secretory activity and in addition contain large numbers of membrane-limited small spheroidal secretion granules.

Hassall's corpuscles are avascular anatomical units and a pericorpuscular zone, at least $50 \mu \mathrm{m}$ broad, is also without blood vessels.

It is therefore suggested that the secretory product(s) of the corpuscular epithelial cells has a purely intrathymic function.

Clark (1963) described electron-dense granules within the cytoplasm of epithelial cells of mouse thymus. This report has been confirmed by Kohnen and Weiss (1964) and similar observations have been made in other species such as the rat (Pfoch, 1971) and the monkey (Chapman and Allan, 1971). These findings have been generally accepted as evidence for secretory activity by the thymus and such behaviour is supported by experimental studies (Metcalf, 1956; Osoba and Miller, 1964). To date there is no evidence that an analogous state of affairs exists in the normal human thymus, although Macadam and Vetters (1969) reported electron-dense secretory granules in an epithelial thymoma as did Kay and Willson (1970) in an ACTH-secreting thymic tumour. Tomasi and Yurchak (1972), in a fluorescence study, described the synthesis of $\mathrm{S}$ component of IgA molecules in human thymic Hassall's corpuscles. We have carried out an electron-microscope examination of 18 human thymuses from 15 cases of myasthenia gravis and three patients with congenital heart disease. Our primary object was the detection of morphological evidence of secretory activity.

\section{Materials and Methods}

All tissues were processed in an identical fashion, namely, glutaraldehyde fixation followed by osmication and araldite embedding. Ultra-thin sections were double-stained with uranyl acetate and lead citrate.

Received for publication 10 January 1973.

\section{Results}

Surprisingly, despite the common impression that Hassall's corpuscles are effete anatomical units, these were the only structures in the thymus which showed evidence of secretory activity. Eleven of the 18 samples of thymus processed for electron microscopy (nine cases of myasthenia gravis and two controls from patients with congenital heart disease) contained Hassall's corpuscles. In all corpuscles the epithelial cells contained the cytoplasmic apparatus (figs 1, 2, and 3) associated with secretery activity of the 'export' type, ie, a product of secretion destined for expulsion from the cell. Rough endoplasmic reticulum, Golgi apparatus, and related small vacuoles were present in all of the epithelial cells. Large numbers of small spheroidal secretion granules were found in every instance (figs 1,2 , and 4). These were limited by a single unit membrane and had an average cliameter of $139 \mathrm{~nm}$. The secretion material consisted of a dense core situated eccentrically within the limiting membrane, the remainder of the secretory vacuole being filled with a less electron-dense material (fig 4). Blood vessels were never detected within Hassall's corpuscles, and a pericorpuscular ring, at least $50 \mu \mathrm{m}$ broad, was similarly avascular.

\section{Discussion}

In the human thymus, organelles other than secretion units which might resemble the structures identified 


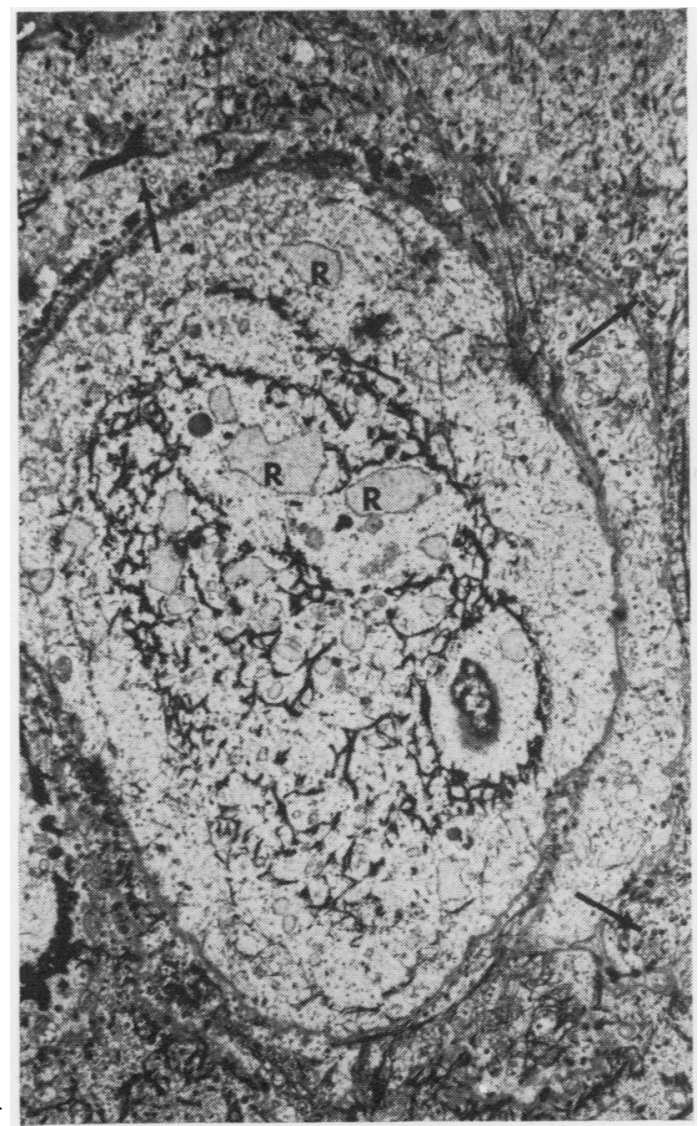

Fig 1

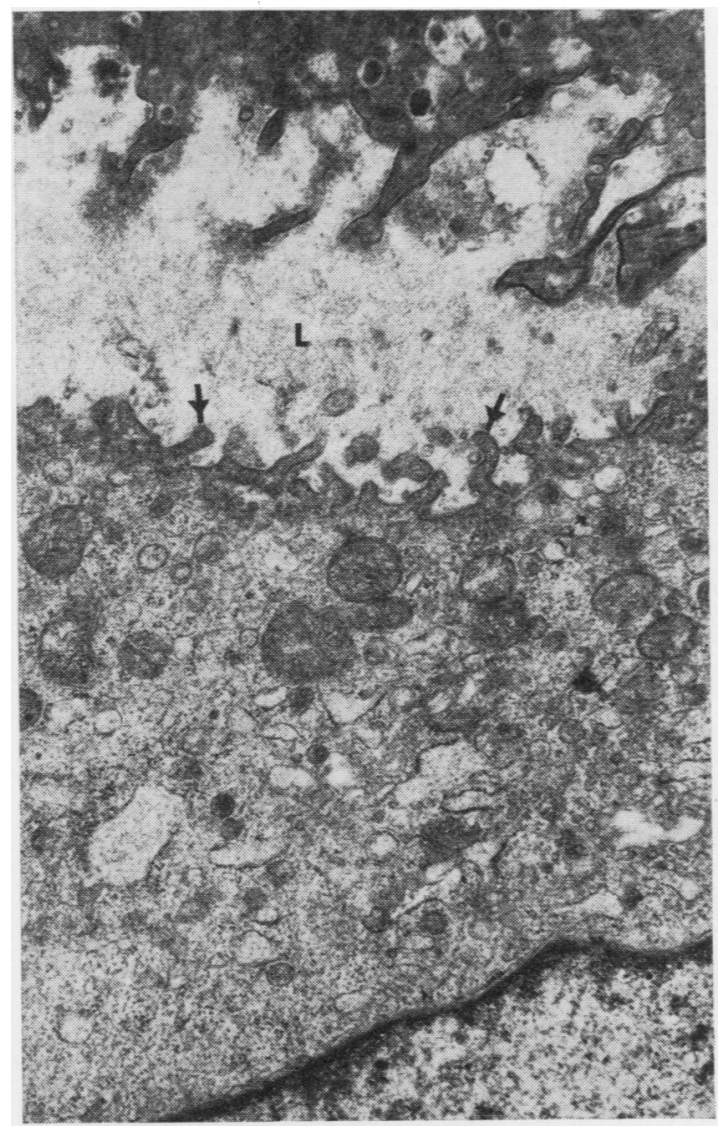

Fig 3

Fig. 1 Low-power view of Hassall's corpuscles. Note the prominent (dilated) units of rough endoplasmic reticulum in the central cells and the large number of small spherical granules (arrows) in the surrounding cells. $\times 1500$

Fig. 3 Part of a 'rosette' of epithelial cells showing microvillous (arrows) cell borders. $L=$ lumen. $\times 6500$.

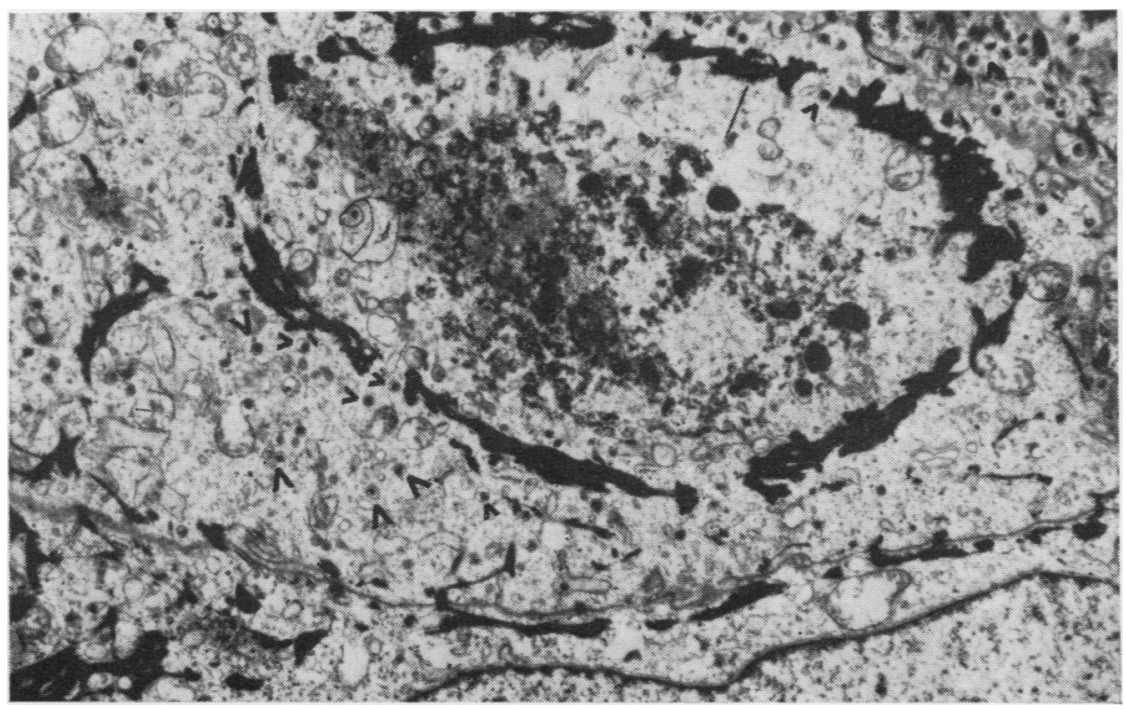

Fig. 2 Higher-power view of Hassall's corpuscular epithelial cells. Note the membrane-bound granules (arrows). $\times 2500$.

Fig 2 


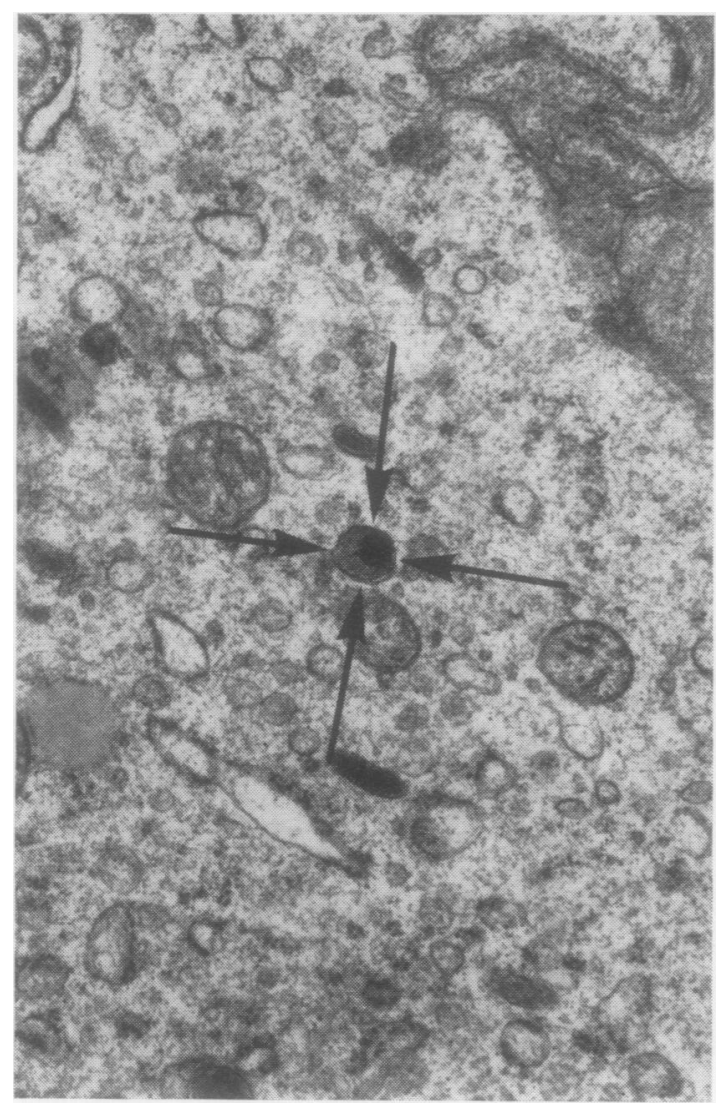

Fig. 4 High magnification of small portion of cytoplasm showing the internal fine structure of an optimally preserved secretion granule (arrowed.) Note the eccentric dense cone and the less dense crescent. $\times 36000$. (Reproduced by permission of the Editor of Lancet.)

are lysosomes, lipid spherules, elements of Golgi complex, and units of smooth endoplasmic reticulum.

Lysosomes are usually larger structures (averaging $500 \mathrm{~nm}$ as opposed to $139 \mathrm{~nm}$ ) and commonly vary in size, shape, intravesicular contents, and 'staining' density. The cells containing them frequently show the activity and general morphology of phagocytes. With the exception of complex lysosomes, ie, autophagic vacuole type, and 'aged' lysosomes, the intravesicular content of lysosomes is homogeneous. The cells of Hassall's corpuscles do not exhibit features suggestive of phagocytic activity and the secretion granules are spheroidal with an eccentric dense core. We have twice attempted unsuccessfully to demonstrate acid phosphatase activity in the granules using the Gomori technique; because the technique may not have been adequate we are reluctant to consider these negative findings as yet being conclusive proof that the structures are not lysosomes.

Lipid spherules, such as those seen in the absorptive cells of the small gut, would resemble the units described above in size and shape. However, their intravesicular material is homogeneous and no evidence exists for unusual lipid metabolic activity in the cells of Hassall's corpuscles.

It is not possible that the appearances we have described are Golgi vesicles. All Hassall's corpuscle cells (except the central effete ones) contain a clearly identifiable Golgi complex. The small secretion units are spatially related to the Golgi complex and perfectly distinct from it.

Spheroidal elements of smooth endoplasmic reticulum comparable in dimensions to the units under discussion are commonly seen in hepatocytes and conceivably could be confused in other cell types for partially depleted (vacuolated) secretion units. The problem does not arise in this case since the cells of Hassall's corpuscles do not contain this organelle. A further fine-structural feature of Hassall's corpuscle organization is the presence of small intracellular and intercellular 'acini' bounded by microvillous cell surfaces. Such appearances are commonly observed in endocrine tissue neoplasms such as intestinal carcinoid tumours (Macadam, Hamilton, and Brown, 1970). In this study, Hassall's corpuscles have been consistently avascular units and a pericorpuscular tissue zone (at least $50 \mu \mathrm{m}$ broad) was similarly devoid of vessels. In view of these features we suggest that the secretion(s) may exert a purely intrathymic regulatory function or be concerned in the transfer of material to lymphocytes.

We therefore consider that our results constitute evidence for possible hormone secretory activity by the epithelial cells of Hassall's corpuscles in the human thymus. The similarity of the structures which we have identified to those described in mouse thymus by Clark (1963) and generally accepted as endocrine secretion granules is further support for our hypothesis.

This work was aided by the McMillan Research Funds of the University of Glasgow.

\section{References}

Chapman, w. L., Jr., and Allen, J. R. (1971). The fine structure of the thymus of fetal and (neonatal monkey (Macaca mulatta). Z. Zellforsch., 114, 220-233.

Clark, S. L., Jr. (1963). The thymus in mice of strain $129 / \mathrm{J}$, studied with the electron microscope. Amer. J. Anat., 112, 1-33.

Kay, S., and Willson, M. A. (1970). Ultrastructural studies of an. ACTH-secreting thymic tumor. Cancer (Philad.), 26, 445-452.

Kohnen, P., and Weiss, L. (1964). An electron microscopic study of thymic corpuscles in the guinea pig and the mouse. Anat. Rec., 148, 29-57.

Macadam, R. F., Hamilton, D. N. H., and Brown, D. B. (1970) Clinical and laboratory studies of an unusual carcinoid tumour. Brit. J. Surg., 57, 17-19. 
Macadam, R. F., and Vetters, J. M. (1969). Fine structural evidence for hormone secretion by a human thymic tumour. J. clin. Path., 22, 407-409.

Metcalf, D. (1956). A lymphocytosis stimulating factor in the plasma of chronic lymphatic leukaemic patients. Brit. J. Cancer, 10, 169-178.

Osoba, D., and Miller, J. F. A. P. (1964). The lymphoid tissues and immune responses of neonatally thymectomized mice bearing thymus tissue in millipore diffusion chambers. J. exp. Med., 119, 177-194.

Pfoch, M. (1971). Vergleichende electronenmikroskopische Untersuchung an entodermalen Thymus-Retikulumzellen neugeborener und alter Wistar-Ratten. Z. Zellforsch., 114, 271-280.

Tomasi, T. B., Jr., and Yurchak, A. M. (1972). The synthesis of secretory component by the human thymus. J. Immunol., 108, 1132-1135.

\section{Addendum}

Since the paper was prepared, we have had the opportunity to examine additional material. These were four thymus glands from patients with myasthenia gravis and eight thymic biopsies obtained during operations to correct congenital heart lesions. All the specimens contained Hassall's corpuscles in which endocrine secretion granules were detectable. We believe that the hormone concerned is probably thymosin.

\section{Reports and Bulletins prepared by the Association of Clinical Biochemists}

The following reports and bulletins are published by the Association of Clinical Biochemists. They may be obtained from The Administrative Office, Association of Clinical Biochemists, 7 Warwick Court, Holborn, London, WC1R 5DP. The prices include postage, but air mail will be charged extra. Overseas readers should remit by British Postal or Money Order. If this is not possible the equivalent of $50 \mathrm{p}$ is the minimum amount that can be accepted.

\section{SCIENTIFIC REPORTS}

3 Automatic Dispensing Pipettes. An assessment of 35 commercial instruments 1967 P. M. G. BROUGHTON, A. H. GOWENLOCK, G. M. WIDDOWSON, and K. A. AHLQUIST $80 \mathrm{p}(\$ 2)$

4 An Evaluation of five Commercial Flame Photometers suitable for the Simultaneous Determination of Sodium and Potassium March 1970 P. M. G. BROUGHTON and J. B. DAWSON $80 p(\$ 2)$

\section{SCIENTIFIC REVIEWS}

1 The Assessment of Thyroid Function March 1971 F. V. FLYNN and J. R. HOBBS 60p (\$1.50)

2 Renal Function Tests Suitable for Clinical Practice January 1972 F. L. MITCHELL, N. VEALL, and R. W. E. WATTS $60 \mathrm{p}(\$ 1.50)$

\section{TECHNICAL BULLETINS}

9 Determination of Urea by AutoAnalyzer November 1966 RUTH M. HASLAM 40p (\$1)

11 Determination of Serum Albumin by AutoAnalyzer using Bromocresol Green October 1967 B. E. NORTHAM and G. M. WIDDOwson 40p (\$1)

13 An Assessment of the Technicon Type II Sampler Unit March 1968 B. C. GRAY and G. K. MoGowAN 40p (\$1)

14 Atomic Absorption Spectroscopy. An outline of its principles and a guide to the selection of instruments May 1968 J. B. DAWSON and P. M. G. BROUGHTON $40 \mathrm{p}(\$ 1)$

15 A Guide to Automatic Pipettes (2nd edition) June 1968 P. M. G. BROUGHTON 40p (\$1)
16 A Guide to Automation in Clinical Chemistry May 1969 P. M. G. BROUGHTON 60p (\$1.50)

17 Flame Photometers (2nd edition) 1969 P. WILDING 60p (\$1.50)

18 Control Solutions for Clinical Biochemistry (4th edition) March 1970 P. M. G. BROUGHTON 60p $(\$ 1.50)$

19 Spectrophotometers. A comparative list of low-priced instruments readily available in Britain May 1970 C. E. WILDE and P. SEWELL 60p (\$1.50)

20 Quantities and Units in Clinical Biochemistry June 1970 P. M. G. BROUGHTON 60p (\$1.50) More than 30 copies in units of 10 at 20p

21 Filter Fluorimeters: A comparative list of 18 instruments September 1970 H. BRAUNSBERG and S. S. BROWN 60p (\$1.50)

22 Bilirubin standards and the Determination of Bilirubin by Manual and Technicon AutoAnalyzer Methods January 1971 BARBARA BILLING, RUTH HASLAM, and N. WALD 60p (\$1.50)

23 Interchangeable Cells for Spectrophotometers and Fluorimeters September 1971 E. S. BROWN and A. H. GOWENLOCK 60p (\$1.50)

24 Simple Tests to Detect Poisons March 1972 B. w. MEADE et al. $60 \mathrm{p}(\$ 1.50)$

25 Blood Gas Analysers May 1972 K. DIXON 60p (\$1.50)

26 Kits for Enzyme Activity Determination September 1972 s. B. ROSALKI and D. TARLOW 80p (\$2.00)

27 Assessment of Pumps Suitable for Incorporation into Existing Continuous Flow Analytical Systems November 1972 A. FLECK et al 60p (\$1.50) 